\title{
RADIOCARBON DATING OF LIME FRACTIONS AND ORGANIC MATERIAL FROM BUILDINGS
}

\author{
MARK J. Y. VAN STRYDONCK ${ }^{1}, K L A A S$ VAN DER BORG ${ }^{2}$, ARIE F. M. DE JONG ${ }^{2}$ and \\ EDUARD KEPPENS ${ }^{3}$
}

\begin{abstract}
We have dated carbonate fractions and organic material from different types of mortar from two sites in Belgium. We demonstrate the difficulties in obtaining good dates from carbonate samples. We also discuss the need for new types of dating material when the mortar comes from contaminated and disturbed sites, where even charcoal can yield aberrant results.
\end{abstract}

\section{INTRODUCTION}

In previous papers we examined the absorption mechanism of $\mathrm{CO}_{2}$ on lime mortar (Pachiaudi et al. 1986; Van Strydonck, Dupas \& Keppens 1989) and its effect on the radiocarbon age and isotope fractionation of different mortar fractions. We have also studied the influence of contamination by fossil carbonate on different fractions (Van Strydonck et al. 1986). In this paper, we investigate different types of samples and compare their (apparent) radiocarbon ages. Where possible, we compared carbonate dates with dates on organic material. We chose locations that represent the worst possible conditions for mortar samples: 1 ) underground ruins, subject to severe perturbation (construction of new walls over older ones, digging of graves); 2) a building facade subject to temperature changes, air pollution and restoration.

\section{ANALYTICAL METHODS}

Charcoal samples were picked from the carbonate matrix and pretreated by the acid-base-acid (ABA) method before combustion. Mortar samples were ground, passed through a $250-\mu \mathrm{m}$ sieve and dried. A small amount of sample was taken to measure its $\mathrm{CO}_{2}$ content. The rest was divided into two parts. From each part, the $\mathrm{CO}_{2}$ was released by a standard $1.15 \mathrm{~N} \mathrm{HCl}$ solution. The reagent was added slowly to the mortar powder, held in suspension in $\mathrm{CO}_{2}$-free water while constantly stirred. From one part, the $\mathrm{CO}_{2}$ was released completely (fraction $=100 \%$ ). The amount of acid added to the second part was just enough to release $10 \%$ of the total $\mathrm{CO}_{2}($ fraction $=10 \%$ ) (Van Strydonck et al. 1986). The one exception was AK-11(ML), where we took the first 22 and $57 \%$. The amount of $\mathrm{CO}_{2}$ was measured by routine chemical analyses (Dupas 1981). If we had enough material, we measured the samples by gas counting. Small samples were AMS dated at Utrecht or Oxford.

\section{SAMPLE DESCRIPTION}

\section{Onze-Lieve-Vrouw Cathedral, Antwerpen, Belgium}

Mortar and charcoal samples were collected during excavation of the foundations of the Romanesque church $\left(50^{\circ} 13^{\prime} 16^{\prime \prime} \mathrm{N}, 4^{\circ} 23^{\prime} 60^{\prime \prime} \mathrm{E}\right)$, demolished when a Gothic cathedral was built over it. The context of this excavation presents a complex situation. At the same site are the remains of the foundations of several churches built in different phases. These construction activities, in addition to many grave trenches, contribute to the disturbance of this subterranean site. Figure 1 shows the locations of the samples relative to the floor plan of the cathedral.

\footnotetext{
${ }^{1}$ Royal Institute of Cultural Heritage, Jubelpark 1, 1040-Brussels, Belgium

${ }^{2}$ State University Utrecht, Princetonplein 5, 3508 TA Utrecht, The Netherlands

${ }^{3}$ Departments of Geochronology and of Applied Geology, Vrije Universiteit, Pleinlaan, 1050 Brussels, Belgium
} 


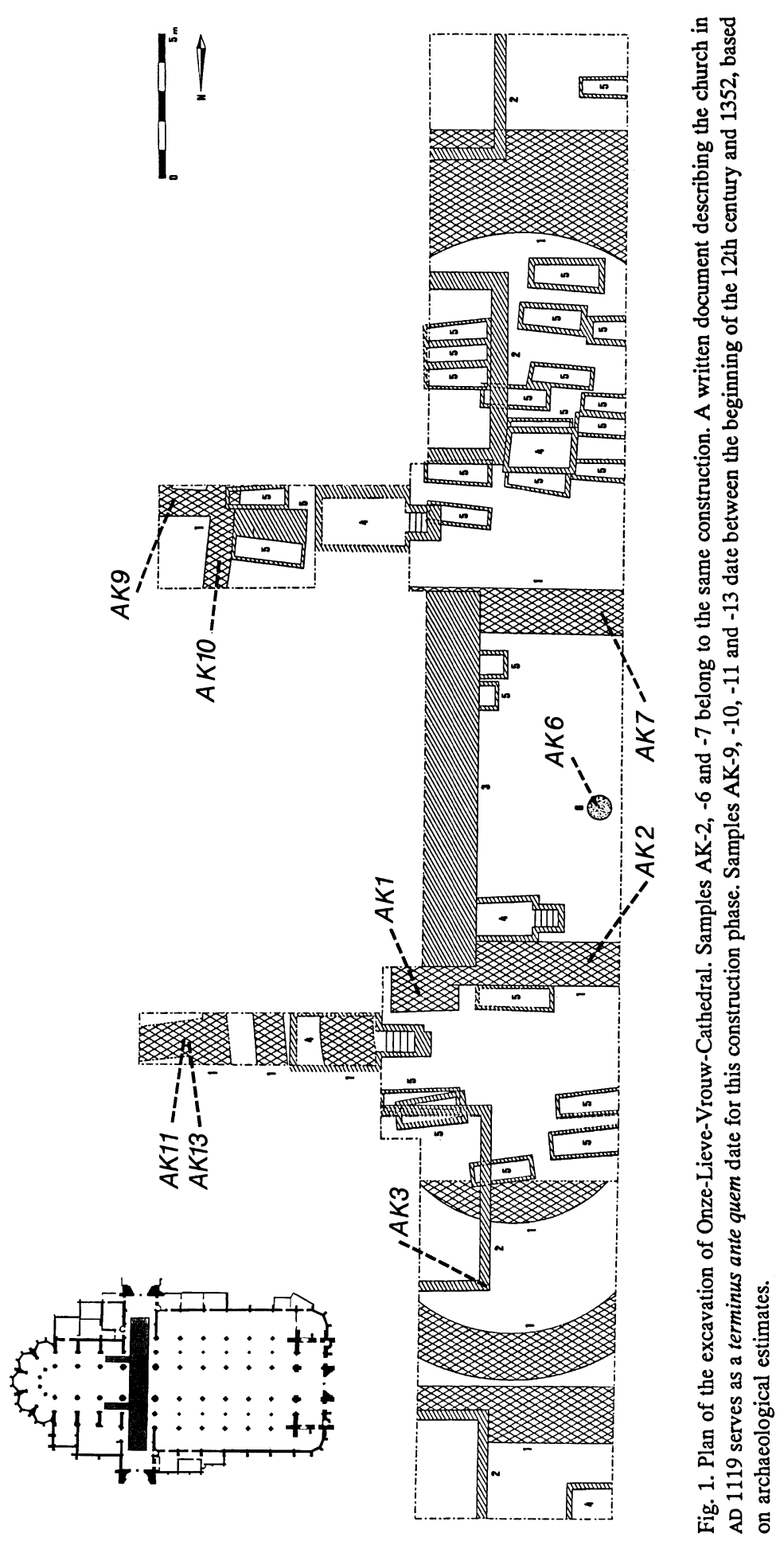




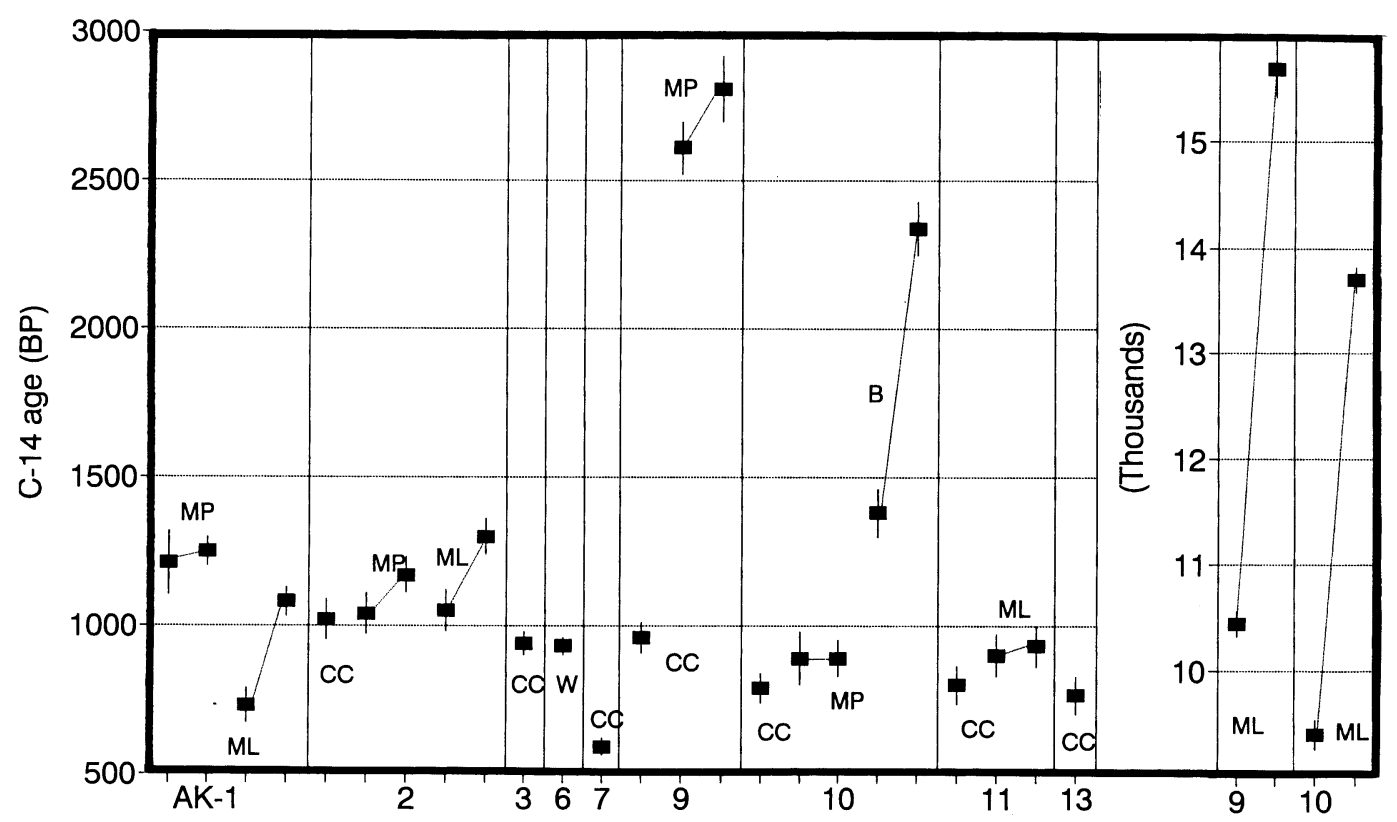

Fig. 2. ${ }^{14} \mathrm{C}$ results of mortar samples from Onze-Lieve-Vrouw Cathedral (uncalibrated $\pm 1 \mathrm{o}$ ). CC-charcoal; MP-mortar powder; ML-mortar lumps; W-wood; B-brown sand.

Figure 2 plots the dates of the samples.

Sample $A K-1$. A very sandy beige mortar powder (MP) containing $2.33 \% \mathrm{CO}_{2}$. In some areas, the mortar forms a conglomerate. Small white nodules (ML) are present in the powder with a maximum diameter of $4 \mathrm{~mm}$ containing $27.8 \% \mathrm{CO}_{2}$.

Sample $A K-2$. From a rather hard brown-gray mortar layer (MP) containing $9.99 \% \mathrm{CO}_{2}$, with very hard white nodules (ML), with varying diameters from about $10 \mathrm{~mm}$ to $5 \mathrm{~cm}$, containing $17.90 \%$ $\mathrm{CO}_{2}$. Shells and some charcoal fragments $(\mathrm{CC})(<0.5 \mathrm{~g})$ were also visible in this layer.

Sample $A K-3$. From a charcoal (CC) layer mixed with sand under tiled pavement ( $>5 \mathrm{~g})$.

Sample AK-6. Twigs (W) that held a wooden well together.

Sample $A K-7.1 .8 \mathrm{~g}$ of small charcoal fragments (CC) from a wall.

Sample $A K$-9. Very powdery mortar (MP) containing $12.75 \% \mathrm{CO}_{2}$ with small white nodules (ML) containing $41.90 \% \mathrm{CO}_{2}$. This high content of $\mathrm{CO}_{2}$ means that the nodules (ML) are almost pure $\mathrm{CaCO}_{3}$. We collected a total amount of $0.27 \mathrm{~g}$ of charcoal (CC) from the lumps.

Sample $A K-10$. Mortar containing several fragments, $1-2.5 \mathrm{~cm}$ long, of a rather large burned wooden branch (diameter $2 \mathrm{~cm}$ ) (CC). The sample is very hard gray-white mortar (MP) containing $20.25 \% \mathrm{CO}_{2}$ with white inclusions (ML) of $100 \% \mathrm{CaCO}_{3}$. Brown sand containing $11.4 \% \mathrm{CO}_{2}$ was collected with the mortar but dated separately (B) and contained large and small mortar nodules.

Sample $A K-11$. White mortar and charcoal from a layer between the top of the foundation wall and the pavement. $\mathrm{CaCO}_{3}$ content of the sample (98\%) indicated complete carbonation of pure lime. We collected about $3 \mathrm{~g}$ of charcoal (CC). 
Sample AK-13. Rather large pieces of charcoal, as in AK-10, collected from the same wall as AK11.

Sample W. $5.97 \mathrm{mg}$ of candle wax.

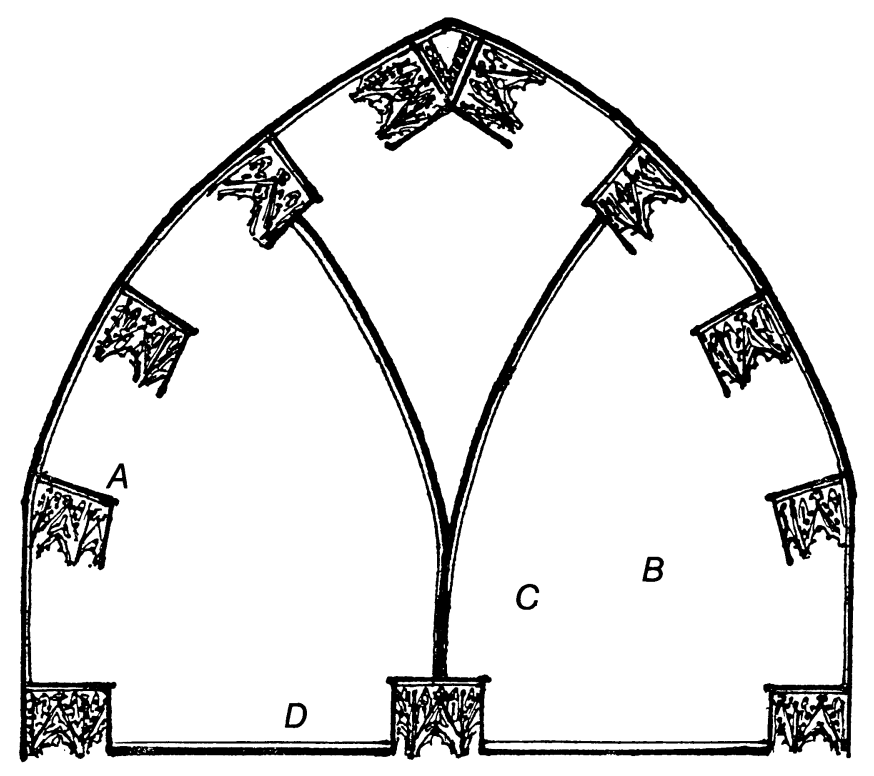

Fig. 3. Plan of the pediment of the portico of the Portail du Bethleem erected in the beginning of the 14th century. A-D indicate sample locations.

\section{Portail du Bethléem, Huy-Liège, Belgium}

We collected mortar samples that served to connect the statues to the pediment of the portico of the Portail du Bethléem at the Cathedral of Huy $\left(50^{\circ} 31^{\prime} \mathrm{N}, 05^{\circ} 14^{\prime} \mathrm{E}\right)$ (Fig. 3). No surface mortar was taken because of the risks of collecting samples contaminated by air pollution.

Samples $A, B, C$. Original mortar from three locations on the pediment. Two samples (a \& b, Fig. 4) were collected from location $\mathrm{B}$. The $\mathrm{CO}_{2}$ content of the carbonate samples varied from 16.51 to $20.89 \%$.

Sample D. Mortar from an ancient restoration with a $\mathrm{CO}_{2}$ content of $18.86 \%$.

Sample $H$. Horse hair used to temper mortar sample D.

\section{RESULTS}

Table 1 and Figures 2 and 4 show the radiocarbon results and isotopic fractionation of each sample and each fraction.

\section{DisCusSION}

\section{Onze-Lieve-Vrouw Cathedral, Antwerpen}

In general, the $\delta^{13} \mathrm{C}$ values confirm the results of our previous study (Van Strydonck et al. 1989). The first fraction is more depleted than the total sample and the heavily contaminated samples have values close to those expected for fossil rock carbonate $(\sim 0 \%)$. Mortar powder tends to yield better ${ }^{14} \mathrm{C}$ results than mortar nodules (Folk \& Valastro 1976, 1979) but the correlation is too vague to be conclusive. In any case, it is no criterion for sample selection. 
TABLE 1. Radiocarbon Measurements of Lime Fractions and Organic Materials

\begin{tabular}{|c|c|c|c|c|}
\hline Sample no. & Lab. no. & $\begin{array}{c}\text { Fraction } \\
(\%)\end{array}$ & $\begin{array}{l}{ }^{14} \mathrm{C} \text { age } \\
\text { (yr BP) }\end{array}$ & $\begin{array}{l}\delta^{13} \mathrm{C} \\
(\% 0)\end{array}$ \\
\hline AK-1(MP-10) & UtC-946 & 10 & $1210 \pm 110$ & -20.3 \\
\hline AK-1(MP-100) & UtC-945 & 100 & $1250 \pm 50$ & -18.5 \\
\hline AK-1(ML-10) & UtC-944 & 10 & $730 \pm 60$ & -18.9 \\
\hline AK-1(ML-100) & UtC-943 & 100 & $1080 \pm 50$ & -17.2 \\
\hline $\mathrm{AK}-2(\mathrm{CC})$ & UtC-998 & & $1020 \pm 70$ & -25.3 \\
\hline AK-2(MP-10) & UtC-983 & 10 & $1040 \pm 70$ & -16.5 \\
\hline AK-2(MP-100) & UtC-984 & 100 & $1170 \pm 60$ & -15.7 \\
\hline AK-2(ML-10) & UtC-985 & 10 & $1050 \pm 70$ & -13.6 \\
\hline AK-2(ML-100) & UtC-986 & 100 & $1300 \pm 60$ & -12.1 \\
\hline $\mathrm{AK}-3(\mathrm{CC})$ & IRPA-948 & & $940 \pm 40$ & -27.0 \\
\hline$A K-6(W)$ & IRPA-967 & & $930 \pm 30$ & -25.3 \\
\hline $\mathrm{AK}-7(\mathrm{CC})$ & UtC-1046 & & $590 \pm 30$ & -26.3 \\
\hline AK-9(CC) & UtC-979 & & $960 \pm 50$ & -25.5 \\
\hline AK-9(MP-10) & UtC-983 & 10 & $2610 \pm 90$ & -14.1 \\
\hline AK-9(MP-100) & UtC-984 & 100 & $2810 \pm 110$ & -13.9 \\
\hline AK-9(ML-10) & UtC-985 & 10 & $10,440 \pm 120$ & -0.3 \\
\hline AK-9(ML-100) & UtC-986 & 100 & $15,680 \pm 260$ & -0.5 \\
\hline $\mathrm{AK}-10(\mathrm{CC})$ & IRPA-972 & & $790 \pm 50$ & -26.5 \\
\hline AK-10(MP-10) & UtC-948 & 10 & $890 \pm 90$ & -15.5 \\
\hline AK-10(MP-100) & UtC-946 & 100 & $890 \pm 60$ & -14.1 \\
\hline AK-10(ML-10) & UtC-950 & 10 & $9390 \pm 140$ & -8.5 \\
\hline AK-10(ML-100) & UtC-949 & 100 & $13,700 \pm 120$ & -2.7 \\
\hline $\mathrm{AK}-10(\mathrm{~B}-10)$ & UtC-952 & 10 & $1380 \pm 80$ & -16.8 \\
\hline AK-10(B-100) & UtC-951 & 100 & $2340 \pm 90$ & -13.8 \\
\hline $\mathrm{AK}-11(\mathrm{CC})$ & IRPA-855 & & $800 \pm 65$ & -26.3 \\
\hline AK-11(ML-22) & OxA-1707 & 22 & $900 \pm 70$ & -16.6 \\
\hline AK-11(ML-57) & OxA-1708 & 57 & $930 \pm 70$ & -11.6 \\
\hline $\mathrm{AK}-13(\mathrm{CC})$ & IRPA-856 & & $765 \pm 65$ & -27.4 \\
\hline W & UtC-1167 & & $480 \pm 60$ & -28.1 \\
\hline A-10 & UtC-992 & 10 & $680 \pm 80$ & -15.1 \\
\hline A-100 & UtC-987 & 100 & $840 \pm 90$ & -11.9 \\
\hline B-10a & UtC-993 & 10 & $790 \pm 90$ & -12.4 \\
\hline B-100a & UtC-988 & 100 & $890 \pm 60$ & -11.6 \\
\hline B-10b & OxA-1709 & 10 & $690 \pm 65$ & -11.6 \\
\hline B-100b & OxA-1710 & 100 & $620 \pm 65$ & -9.9 \\
\hline$C-10$ & UtC-994 & 10 & $800 \pm 80$ & -12.5 \\
\hline C-100 & UtC-989 & 100 & $850 \pm 80$ & -11.8 \\
\hline D-10 & UtC-995 & 10 & $550 \pm 70$ & -12.5 \\
\hline D-100 & UtC-990 & 100 & $680 \pm 60$ & -13.0 \\
\hline $\mathrm{H}$ & UtC-991 & & $410 \pm 90$ & -23.1 \\
\hline
\end{tabular}




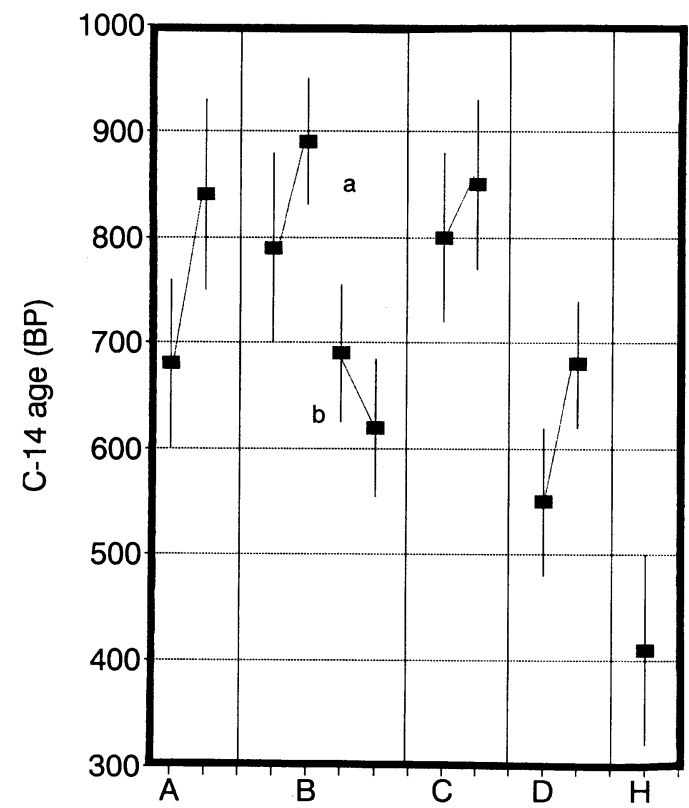

Fig. $4 .{ }^{14} \mathrm{C}$ results of mortar samples from Portail du Bethléem (uncalibrated \pm 1 o)

The sample ages of charcoal, mortar nodules and powder agree very well for AK-2. It was the only sample that had the same characteristics (solidity, homogeneity, color, etc.) as the good-quality mortars found in the standing walls. The results show very clearly that fossil carbonate is the major cause of the deviant results.

The charcoal in the samples showed other dating problems. Based on archaeological estimates, samples AK-2, -6 and -7 should come from the same construction phase, and samples AK-9, -10 , -11 and -13 from another. Thus, AK-7 appears to be too young and AK-9 too old. Presumably, these are all sample errors, which means that the samples of charcoal and mortar lumps are reworked or from a younger inclusion. To overcome this general problem of dating a building, we asked the archaeologists and restorers to find samples with a closer relationship between the material and the historical event to be dated. A first and very important measurement was executed on a drop of candle wax (W), which was stuck between a wall painting and its painted-over surface. The result, cal AD 1396-1472 (1 o), agrees with stylistic and stratigraphic estimates (Van Strydonck 1990).

\section{Portail du Bethléem, Huy-Liège, Belgium}

The two fractions of the original mortar samples do not show the same important age differences as in the previous case. The mean age of samples A-10, B-10a, B-10b and C-10, $740 \pm 63 \mathrm{BP}$, cal AD 1215-1297 (1 o) is comparable, but older than the historic date (beginning of the 14th century). The results show very clearly the lack of accuracy in mortar dating, even when only a small amount of fossil carbonate is present. We also found a different type of sample, horse hair, which was used to temper the mortar.

\section{CONCLUSION}

The organic material in this study yielded better results than those of Tubbs and Kinder (1990), who obtained very old ages on organic material in lime mortar, because we tried to collect only 
samples that were expected to be contemporaneous with an archaeological event. At first, we searched only for charcoal, but later tried to find material with a more specific origin.

The results of the carbonate samples show a large scatter not only among samples, but also within one sample. Good results are possible only if the mortar is of high quality, which is not often the case in building foundations.

\section{ACKNOWLEDGMENT}

The authors wish to thank the AMS laboratory of Oxford for the measurements made on some of the samples.

\section{REFERENCES}

Dupas, M. 1981 Méthodes d'analyse chimique appliquées à l'étude de l'altération et de la conservation des matériaux pierreux. In The Conservation of Stone 2, Proceedings. Bologna, Centro Conservazione Sculture all'Aperto: 455-464.

Folk, R. L. and Valastro, S. 1976 Successful technique for dating of lime mortar by carbon-14. Journal of Field Archaeology 3: 203-208.

1979 Dating of lime by ${ }^{14} \mathrm{C}$. In Berger, R. and Suess, H. E., eds., Radiocarbon Dating, Proceedings of the 9th International ${ }^{14} \mathrm{C}$ Conference. Berkeley, University of California Press: 721-732.

Pachiaudi, C., Maréchal, J., Van Strydonck, M., Dupas, M. and Dauchot-Dehon, M. 1986 Isotopic fractionation of carbon during $\mathrm{CO}_{2}$ absorption by mortar. In Stuiver, M. and Kra, R. S., eds., Proceedings of the 12th International ${ }^{14} \mathrm{C}$ Conference. Radiocarbon 28 (2A): 691-697.

Tubbs, L. E. and Kinder, T. N. 1990 The use of AMS for the dating of lime mortars. In Yiou, F. and
Raisbeck, G. M., eds., Proceedings of the 5th International Conference on Accelerator Mass Spectrometry. Nuclear Instruments and Methods B52: 438-441.

Van Strydonck, M. 1990 Radiokoolstofdatering van een druppel kaarsvet. Monumenten en Landschappen 9(5): 36-37.

Van Strydonck, M., Dupas, M., Dauchot-Dehon, M., Pachiaudi, C. and Maréchal, J. 1986 The influence of contaminating (fossil) carbonate and the variations of ${ }^{13} \mathrm{C}$ in mortar dating. In Stuiver, M. and Kra, R. S., eds., Proceedings of the 12 th International ${ }^{14} \mathrm{C}$ Conference. Radiocarbon 28(2A): 702-710.

Van Strydonck, M., Dupas, M. and Keppens, E. 1989 Isotopic fractionation of oxygen and carbon in lime mortar under natural environmental conditions. In Long, A. and Kra, R. S., eds., Proceedings of the 13th International ${ }^{14} \mathrm{C}$ Conference. Radiocarbon 31(3): 610-618. 